\title{
Gap between Public and Private Wages and Wages Determination in the Public Sector
}

\author{
Diferença entre salários públicos e privados \\ e fixação de salários no setor público
}

NELSON MARCONI*

RESUMO: Este estudo verifica, em primeiro lugar, a existência de segmentação entre os mercados de trabalho público e privado no Brasil por meio da análise do comportamento do emprego e dos salários nesses mercados durante a década de 1990, mostrando que a diferença salarial dos trabalhadores de ambos os setores aumentou de maneira favorável aos servidores públicos nesse período. Posteriormente, o estudo analisa os fatores que influenciam especificamente a fixação de salários no setor público, o que explicaria a existência desse gap, por meio de uma discussão teórica seguida da aplicação de testes econométricos. PALAVRAS-CHAVE: Diferenciais de salário; mercados de trabalho do setor público; salários públicos e privados.

ABSTRACT: This study verifies, first of all, the existence of segmentation between the public and private labour markets in Brazil by means of the analysis of the behaviour of employment and wages in those markets during the 1990's, showing that the con-trolled wage gap between the workers of both sectors have increased in a manner favourable to civil servants in this period. Later on, the study analyses the factors that specifically influence the wage setting in the public sector, which would account for the existence of such gap, by means of a theoretical discussion followed by the application of econometric tests.

KEYWORDS: Wage differentials; public sector labor markets; public and private wages. JEL Classification: J31; J45.

This article is aimed at establishing some rules that govern the process of wage setting in the public sector starting from the analysis of the behaviour of the wages of state civil servants. ${ }^{1}$ At first the article will present a brief diagnosis of the behaviour of the labour markets of the public and private sectors during the 1990s.

\footnotetext{
* Doctor in economics by Fundação Getúlio Vargas, São Paulo/SP, Brasil. E-mail: nmarconi@uol.com. br. Submitted: July 2002; accepted: March 2003.

${ }^{1}$ Since Brazil is a federative republic, the term "state civil servants" refers to the members of the civil service of the different federal states, as opposed to federal civil servants.
} 
In the second section, a general model for the wage setting will be developed; this model will allow for an analysis of the controlled gap in terms of compensation between the workers of both sectors and will highlight the existence of segmentation between such markets, since the average wage in the public sector will be higher for individuals having similar personal characteristics. The third section will deal with the discussion about the factors that specifically influence the determination of wages in the public sector and that would contribute for the existence of this wage gap even after the inclusion of controls for the characteristics of employees. In the last section, we shall be carrying out the tests aimed at empirically verifying if such factors really influence the wage setting for employees in the public sector, starting from the analysis of the data pertaining to state statute-governed civil servants. $^{2}$

\section{THE INITIAL DIAGNOSIS}

The purpose of this diagnosis is to demonstrate the evolution of employment and average real wage during the period taken into account (1993, 1996 and 1999), starting from the data of PNAD and to allow for an initial evaluation of the differences between the behaviour of the labour markets of the private and public sectors, highlighting in this latest one the three spheres of government.

The database used for the tests is made up particularly of PNAD - National Research by Household Sampling -, prepared by IBGE. PNAD's of three years of this decade - 1993, 1996 and 1999 - have been used, aimed at allowing for, in addition to the cross-section analyses, the study of the temporal evolution of the variables analysed and, therefore, of the behaviour of these markets during the 1990s and the process of adjustment the labour market of the public sector went through in this period.

The universe taken into account in the calculations presented includes the persons employed (self-employed people, household help and employers have been excluded), with ages between 18 and 65, of urban areas of the country, in order to allow for the approximation between some characteristics of the public and private labour markets. ${ }^{3}$ Information that did not specify whether the worker operated in

\footnotetext{
${ }^{2}$ We have chosen to analyse the case of state civil servants because their wages are influenced by the conditions of the local labour markets, as we shall see later on, which makes the analysis relevant for some of these conditions would also influence the wage setting in the private sector and, even so, they would not be enough to eliminate the wage gap recorded. Furthermore, the group of state civil servants, among which the statute-governed civil servants, is the most numerous within the whole body of civil servants.

${ }^{3}$ There are no self-employed people or employers in the public sector and the open competitions and simplified selection procedures impose as a requirement for admission, in general, the minimum age of 18. Furthermore, it is not usual that a civil servant carries out his or her activities in the so-called rural areas, except in very isolated cases, such as agricultural inspection or border inspection.
} 
the public or in the private sector was disregarded and only information pertaining to the main activity of the person was included, since the secondary occupation has specific characteristics and, once included, it might distort the results. The resulting samples include, for each year, circa 60,000 individuals. In order to allow for the comparison between the individual wages, these amounts have been adjusted by means of their division by the number of hours worked in the week and later through the multiplication by 44 . With this, one calculates the amount of all wages for a uniform weekly workload of 44 hours. $^{4}$

The data have been initially segmented between the private and public sectors in general and, in this last group, between statute-governed civil servants, the Military and workers governed by the Consolidation of Labour Acts. This division is justified because while the wage of statute-governed civil servants and of the Military is defined by the legislation and, theoretically, in an unilateral manner, the wages of the workers governed by the Consolidation of Labour Acts are the result of negotiations and can be defined by arbitration, which brings about relatively different processes for the establishment of the compensation. Furthermore, the behaviour of wages and employment in this segment has been quite different from the one recorded for statute-governed civil servants during the decade, as we shall see later on.

The data of table 1 indicate that the total of public jobs has remained practically stable during the decade, while their participation in total employment has undergone a slight drop, which indicates that approximately $1 / 4$ of the universe of workers taken into account (only employees between ages 18 and 65) is in the public sector.

When one assesses the make-up of public employment, however, one notices that the evolution has not been uniform: although in general it has remained relatively stable, one notices an accentuated growth in municipalities and a reduction in the federal and state spheres, particularly among workers governed by the Consolidation of Labour Acts. It is most likely that such behaviour has been a result of the process of privatization, since in the state-owned companies there are no statute-governed civil servants.

\footnotetext{
${ }^{4}$ This calculation presupposes that the amount of the wage per hour does not change according to the number of hours worked (at least up to the limit of 44 hours). In practice, this is true for the Brazilian case, for up to this limit the legislation establishes the same wage per hour and the payment of overtime starts thereafter.
} 
Table 1: Level of Employment Per Sector and Work Regime (employees aged 18 to 65)

\begin{tabular}{|c|c|c|c|c|c|c|c|c|c|}
\hline \multicolumn{4}{|c|}{$\begin{array}{c}\text { Number of employees } \\
\text { (in thousands) }\end{array}$} & \multicolumn{3}{|c|}{ Index $(1993=100)$} & \multicolumn{3}{|c|}{$\begin{array}{l}\% \text { participation in } \\
\text { total of employees }\end{array}$} \\
\hline & 1993 & 1996 & 1999 & 1993 & 1996 & 1999 & 1993 & 1996 & 1999 \\
\hline PRIVATE & 18,613 & 20,227 & 21,173 & 100 & 109 & 114 & 73 & 75 & 76 \\
\hline PUBLIC & 6,930 & 6,925 & 6,853 & 100 & 100 & 99 & 27 & 26 & 25 \\
\hline Federal & 1,392 & 1,373 & 1,224 & 100 & 99 & 88 & 6 & 5 & 4 \\
\hline SGCS + Military & 845 & 877 & 801 & 100 & 104 & 95 & 3 & 3 & 3 \\
\hline SGCS & 603 & 602 & 525 & 100 & 100 & 87 & 2 & 2 & 2 \\
\hline Military & 242 & 275 & 275 & 100 & 114 & 114 & 1 & 1 & 1 \\
\hline EGCLA & 547 & 495 & 423 & 100 & 91 & 77 & 2 & 2 & 2 \\
\hline State & 3,245 & 3,102 & 2,898 & 100 & 96 & 89 & 13 & 11 & 10 \\
\hline SGCS & 2,068 & 2,156 & 2,105 & 100 & 104 & 102 & 8 & 8 & 8 \\
\hline EGCLA & 1,177 & 946 & 793 & 100 & 80 & 67 & 5 & 4 & 3 \\
\hline Municipality & 2,292 & 2,449 & 2,730 & 100 & 107 & 119 & 9 & 9 & 10 \\
\hline SGCS & 930 & 1,187 & 1,418 & 100 & 128 & 153 & 4 & 4 & 5 \\
\hline EGCLA & 1,361 & 1,262 & 1,311 & 100 & 93 & 96 & 5 & 5 & 5 \\
\hline Total SGCS & 3,601 & 3,945 & 4,049 & 100 & 110 & 112 & 14 & 15 & 14 \\
\hline Total EGCLA & 3,086 & 2,703 & 2,528 & 100 & 88 & 82 & 12 & 10 & 9 \\
\hline Total Military & 242 & 275 & 275 & 100 & 114 & 114 & 1 & 1 & 1 \\
\hline Grand total & 25,543 & 27,152 & 28,027 & 100 & 106 & 110 & 100 & 100 & 100 \\
\hline
\end{tabular}

SGCS - Statute-governed civil servants

EGCLA - Employees governed by the Consolidation of Labour Acts ${ }^{5}$

In turn, the data pertaining to the evolution of the average real wage of public servants (included in table 2), contrary to the level of employment, has shown quite an increase during the decade. With the exception of the workers governed by the Consolidation of Labour Acts - basically in the federal and state levels of government - , the wage of the other categories of civil servants included in the table has shown higher growth than the one recorded for privatesector workers between 1993 and 1999. Table 2. Average Real Wage and Public / Private Wage Gap

${ }^{5}$ Consolidation of Labour Acts (CLT) is a set of acts concerning labour relations enacted in 1943. Brazilian government employees can be either hired by the statute of civil servants or by CLT, according to the type of organization, function and model of recruitment. 
Table 2. Average Real Wage and Public / Private Wage Gap (amounts for September 1999 - deflation factor: INPC)

\begin{tabular}{|c|c|c|c|c|c|c|c|c|c|}
\hline \multicolumn{4}{|c|}{ Amount } & \multicolumn{3}{|c|}{ Index $(1993=100)$} & \multicolumn{3}{|c|}{$\begin{array}{c}\text { Public / private } \\
\text { gross wage } \\
\text { gap (in \%) }\end{array}$} \\
\hline & 1993 & 1996 & 1999 & 1993 & 1996 & 1999 & 1993 & 1996 & 1999 \\
\hline PRIVATE & 454 & 562 & 527 & 100 & 124 & 116 & & & \\
\hline PUBLIC & 816 & 1.001 & 990 & 100 & 123 & 121 & 80 & 78 & 88 \\
\hline Federal & 1.44 & 1.512 & 1.598 & 100 & 105 & 111 & 217 & 169 & 203 \\
\hline SGCS + Military & 1.304 & 1.565 & 1.705 & 100 & 120 & 131 & 187 & 178 & 223 \\
\hline SGCS & 1.511 & 1.764 & 2.014 & 100 & 117 & 133 & 233 & 214 & 282 \\
\hline Military & 762 & 1.08 & 1.069 & 100 & 142 & 140 & 68 & 92 & 103 \\
\hline EGCLA & 1.656 & 1.412 & 1.400 & 100 & 85 & 85 & 264 & 151 & 166 \\
\hline State & 783 & 1.029 & 1.038 & 100 & 131 & 132 & 72 & 83 & 97 \\
\hline SGCS & 777 & 1.041 & 1.082 & 100 & 134 & 139 & 71 & 85 & 105 \\
\hline EGCLA & 795 & 1.001 & 925 & 100 & 126 & 116 & 75 & 78 & 75 \\
\hline Municipality & 395 & 607 & 598 & 100 & 154 & 151 & -13 & 8 & 13 \\
\hline SGCS & 480 & 690 & 661 & 100 & 144 & 138 & 6 & 23 & 25 \\
\hline EGCLA & 333 & 527 & 528 & 100 & 158 & 158 & -27 & -6 & 0 \\
\hline Total SGCS & 846 & 1.074 & 1.083 & 100 & 127 & 128 & 86 & 91 & 105 \\
\hline Total EGCLA & 785 & 880 & 829 & 100 & 112 & 106 & 73 & 56 & 57 \\
\hline Total Military & 762 & 1.080 & 1.069 & 100 & 142 & 140 & 68 & 92 & 103 \\
\hline
\end{tabular}

Table 2 also shows the gross gap (without controls concerning demographic and productive characteristics) of the average wage between the public (and the segments here taken into account) and private sectors. During the decade, all categories of civil servants included in the table started being paid equal or higher wages, and the gap rose (except for the workers governed by the Consolidation of Labour Acts) as a consequence of the different evolution of wages in the public and private sectors in the period. ${ }^{6}$

The data presented in this initial diagnosis show that, in view of the fiscal crisis, the government authorities seem to have chosen the improvement of the average wage, above the growth recorded in the private market, and to have given up an increase in public employment (which in aggregate terms has remained prac-

\footnotetext{
${ }^{6}$ Municipality civil servants were paid wages relatively smaller at the beginning of the decade, but at the end of the period they were already paid equivalent or higher compensations.
} 
tically stable) during the decade. As a matter of fact, the adjustment has more intensely affected the civil servants governed by the Consolidation of Labour Acts (although the wage gap for this group remains positive), which is possibly explained by the process of privatization. ${ }^{7}$ Therefore, the rulers and bureaucrats decided, during the process of adjustment public sector is going through, to better protect the wage levels than the level of employment. As a result of this whole scenario, the gross gap of wages between the public and the private sector has increased between 1993 and 1999.

\section{THE GENERAL MODEL OF WAGE DETERMINATION AND THE WAGE GAP WITH CONTROLS}

The calculation of the gross gap presented in the previous section does not take into account any sort of control with regard to the personal characteristics that will influence the wage gap (or the relative salary) of individuals. As a matter of fact, part of the gross gap must be explained by the differences in terms of the demographic and productive characteristics of people who make up the public and private sectors. Therefore, it is necessary to compare the wage for workers with identical characteristics, each of them working in one of the sectors, in order to evaluate whether effectively the wages paid for both are different, which would constitute the segmentation between the two labour markets. This will be the test that will be carried out in this section. ${ }^{8}$

The equation adopted in this study will utilize a semi-log model, which allows for the measurement of the proportional (or relative) variation that an absolute variation in the explicative variable brings about on a dependant variable. In order to capture the relative oscillations that the explicative variables bring about on an endogenous variable, it is necessary to calculate the anti-log of the coefficient of the former and subtract 1 . The tables pertaining to the regressions developed in this

\footnotetext{
${ }^{7}$ And by the establishment of the single legal regime in the Constitution of 1988, since the vacant post corresponding to a worker governed by the Consolidation of Labour Acts who retired was not filled by another civil servant (where appropriate) hired under this work regime, but instead by a statutegoverned civil servant (in the ministries and agencies; in the public enterprises, the work regime remained the same).

${ }^{8}$ In Brazil, the first author to deal with the issue was Macedo (1985), and other relevant texts on the matter are those of Urani and Ramalho (1995), Gill and others (1997) and Barros and others (1997). The results of the works of Macedo and those of Barros and others will demonstrate starting from different samples (RAIS or PNADS) and different periods that, even after the inclusion of controls, the average wage of civil servants is higher than those paid in the private sector. Gill and others (1997) also present a similar conclusion. The study of Urani and Ramalho (1995), in turn, will analyse the gap by educational groups and is the only one that achieves different conclusions, showing that during the 1980s only the group of civil servants that has less than a year of schooling presented a positive wage gap, the gap being negative and growing for the other groups to the extent that people with more schooling were included in the analysis.
} 
work present the results under this form of calculation and already multiplied by 100 , in order to facilitate the visualization of such impact from the percentage point of view.

The coefficient of the dummy pertaining to the (public or private) sector will be measuring the percentage gap between the geometric averages of wage practised in the two sectors for workers having identical personal characteristics (since the other factors that influence this gap will already be controlled, by means of the inclusion of other dummies that will measure the effects the different characteristics of workers exercise on the wage gap).

The most general model for the determination of the wage structure utilized in the regression defines that the compensation of a given worker will depend on his or her personal characteristics (demographic and productive) and on a series of variables that will change the level of wage defined for such characteristics (or that may change the return workers receive by virtue of having such characteristics).$^{9}$

The personal characteristics would be divided in two subgroups: the demographic and the productive ones. The demographic personal characteristics would include gender, colour and age. These characteristics - emphasising the two first ones, although the third one may suffer from the same problem - may be the target of discrimination and imply the payment of different compensations even if the levels of productivity (or the productive characteristics) are similar.

The productive characteristics would correspond to those that would directly influence the capability and the skills acquired for work and, consequently, the very productivity of employees. This group would include the educational level of the individual, the work experience and, somehow, age, which may also capture some effect of changes in the productive capability if the individual continually invests in training, as well as if he or she remains employed as time goes by and thus increases his or her work experience. ${ }^{10}$

The other group of variables that will contribute to the wage setting - changing the level deriving from the set of personal characteristics - will be made up of the so-called institutional variables that measure the degree of unionization and the geographic location of workers.

The geographic location of workers will be a variable that will try to capture the explanatory power of some non-pecuniary aspects on the wage setting, such as the conditions of living in the different cities, and of the regional differences between the structures of labour markets. In turn, the bargaining power of workers (represented by the degree of adherence to trade unions ${ }^{11}$ ) may bring about, should

\footnotetext{
${ }^{9}$ The influence of the different personal characteristics in the wage setting, in turn, also depends on the supply of and on the demand for each of them.

${ }^{10}$ In addition to reflecting the specific human capital of the individual, the number of years of service in the same enterprise may also correspond to an indicator of its turnover rate, which, in turn, may have influence on the wage setting.

${ }^{11}$ Note that the two variables do not have similar meanings, because, as a matter of fact, the degree of
} 
the employee be a member of a trade union and benefit from its negotiations, a calculated bonus on the wage that would be a result of the personal characteristics observed for this worker.

Therefore, the wage of an individual would be equivalent to:

$W_{i}=W_{i c} *\left(1+R_{i}\right)$,

$W_{i c}=f$ (gender, colour, age, schooling, work experience) $R_{i}=f$ (geographic location and bargaining power of workers) Where:

$W_{i}=$ wage of the individual $i$

$W_{i c}=$ portion of the wage of the individual $i$ that depends on his or her demographic and productive characteristics

$R_{i}=$ other variables that will change the value of $W_{i c}$; the interaction of this set of variables will determine a value for $R_{i}$ that will make $W_{i}$ oscillate around $W$ ${ }_{i c}$, ergo $R_{i}$ may be considered a bonus or an economic rent upon the wage determined by the personal characteristics.

And the format of the equation adopted in the regressions will be the following:

$L n W_{i}=a+\left(b *\right.$ sector $\left._{i}\right)+\left(c *\right.$ age $\left._{i}\right)+\left(d *\right.$ age $\left._{i}{ }^{2}\right)+\left(e^{*}\right.$ gender $\left._{i}\right)+(f *$ years of study $\left._{i}\right)+\left(g * \operatorname{colour}_{i}\right)+(b *$ years of experience $i)+\left(j *\right.$ state $\left._{i}\right)+\left(k *\right.$ trade union $\left._{i}\right)$ Where:

$L n W_{i}=$ natural logarithm of the wage of the individual $i$, adjusted for the number of hours worked

sector $=$ indicative dummy of the sector in which the individual i operates (public or private). It assumes the value of one if he is in the public sector and it will capture the controlled wage gap between civil servants and the workers of the private sector;

age $=$ age of the individual $i$ (as one of the proxies for experience or specific human capital);

age $^{2}=$ age elevated to the second power of the individual $i$ (in order to capture the format of the curb of returns associated to the evolution of the experience, a negative coefficient being expected, which indicates the concavity of this function);

gender $=$ dummy pertaining to the gender of the individual $i$ (that assumes the value of one if the individual is a man), in order to capture the effects of discrimination;

years of study $=$ number of years of study of the individual $i$ (trying to evaluate the impact of the stock of general human capital);

colour $=$ dummy pertaining to the colour of the individual $i$ (one if the individual is white), also in order to capture the effects of discrimination;

years of experience $=$ number of years in which the individual $i$ has been working in that job (also as a proxy of the specific human capital);

state $=$ dummy pertaining to the state in which the individual $i$ works (assuming a value equal to one for the state in which the person lives; one dummy being 
created for each state, being the dummy of control the Federal District; the comparison will be made between the Federal District and each state but not among states);

trade union $=$ dummy pertaining to the membership of the individual $i$ in some trade union (it will assume a value equal to one if the worker is a member of an entity of this sort).

The regressions for the years taken into account (1993, 1996 and 1999) were carried out based upon this equation by the method of the ordinary least squares, and each of them included in the sample the individuals who work in the private sector and those belonging to the segment of the public sector taken into account in the respective calculation.

Table 3. Public / Private Wage Gap - controlled - in \%

\begin{tabular}{lccc}
\hline & 1993 & 1996 & 1999 \\
\hline PRIVATE & & & \\
\hline PUBLIC & 7 & 8 & 16 \\
\hline Federal & 51 & 45 & 56 \\
\hline SGCS + Military & 41 & 50 & 65 \\
\hline \multicolumn{1}{c}{ SGCS } & 54 & 61 & 76 \\
\hline \multicolumn{1}{c}{ Military } & 14 & 29 & 47 \\
\hline EGCLA & 71 & 40 & 44 \\
\hline SGCS & 8 & 8 & 17 \\
\hline EGCLA & 2 & 7 & 16 \\
\hline Municipality & 16 & 12 & 19 \\
\hline SGCS & -13 & -7 & 1 \\
\hline EGCLA & -10 & -4 & 1 \\
\hline Total SGCS & -17 & -10 & 1 \\
\hline Total EGCLA & 7 & 10 & 17 \\
\hline Total Military & 9 & 6 & 14 \\
\hline
\end{tabular}

* 1999 non-significant at 5\%

Table 3 reports the controlled wage gap between the workers of the public and private sectors deriving from the regressions carried out. ${ }^{12}$ One notices at first that the gaps substantially reduce vis-à-vis those recorded in table 2 , to which in the control pertaining to personal characteristics had not been added. Therefore, the

\footnotetext{
12 The $r^{2}$ is not presented because each number that makes up the table 3 is the result of a different regression and the list of coefficients would be too long; however, none of them remained under 0,4. The same applies to table 4 .
} 
differences in the make-up of the labour force between the two sectors explain a significant part of the gross wage gap (non-controlled).

Even so, the addition of the variables of control to the analysis shows that even taking into account the differences in the demographic and productive characteristics of workers and the institutional environment in the two sectors, the wage gap remains positive for the civil servants in most of the observed cases (it is negative in 1993 and 1996 and it is statistically null only in 1999 for the municipality civil servants). Therefore, one can recognize the existence of segmentation between the two markets, since individuals with similar characteristics are not paid equal compensations in the two sectors.

Different analyses on the wage gap that exists between the workers of the two sectors conclude that, although, as an average, the public sector pays higher wages to its employees than those paid by the private sector, this behaviour would not be uniform when the labour force was stratified according to the different levels of qualification. Better-qualified workers would be paid smaller wages in the public sector, while the less qualified would be paid compensations above those recorded for their peers in the private sector. Thus, the amplitude of wage ranges would be smaller in the public sector (and probably the distribution of income would be less unequal), but in counterpart the compensation system becomes less efficient in terms of attraction and retention of qualified employees.

In order to analyse this matter, we shall carry out an analysis stratified as per intervals of years of study to evaluate whether the controlled wage gap changes for each of the groups. Workers will be divided according to their level of schooling: 0 to 4 years of study, 5 to 8,9 to 11 and 12 or more. The other controls adopted in the previous equations will be maintained and the tests will be carried out for Statute-governed civil servants.

We chose to carry out an analysis limited to Statute-governed civil servants because the set of occupations exercised by employees governed by the Consolidation of Labour Act is too comprehensive. The excessive heterogeneity of occupations might jeopardize the analysis. Furthermore, this restriction may be interesting because Statute-governed civil servants are the most characteristic type of civil servant, since the legal framework that influences the definition of their compensation is different from the one adopted in the private sector and also in force for civil servants governed by the Consolidation of Labour Acts.

The results of the regressions controlled according to years of study show that there have been changes in the controlled wage gap, stratified according to the level of schooling, during the 1990s. While in 1993 and 1996 the gap was negative for the state civil servants with a higher degree of schooling and the municipality civil servants in general, in 1999 it became statistically non-significant for these groups, with the exception of the ones having had more schooling in the municipalities, the only segment whose gap remained negative at the end of the decade, that is, who were paid wages below those practised in the private sector (taking into account the inclusion of controls). In the other cases, the wages are higher in public administration for individuals with similar characteristics. 
Table 4. Wage Gap

Statute-Governed Civil Servants / Private Workers controlled and segmented per years of study — in \%

\begin{tabular}{|c|c|c|c|c|c|c|c|c|c|}
\hline \multicolumn{4}{|c|}{$\begin{array}{c}\text { (Federal + Military) } / \\
\text { Private }\end{array}$} & \multicolumn{3}{|c|}{$\begin{array}{l}\text { State / } \\
\text { Private }\end{array}$} & \multicolumn{3}{|c|}{$\begin{array}{l}\text { Municipality / } \\
\text { Private }\end{array}$} \\
\hline & 1993 & 1996 & 1999 & 1993 & 1996 & 1999 & 1993 & 1996 & 1999 \\
\hline $0-4$ years & 78 & 92 & 131 & 32 & 33 & 30 & -10 & -10 & $-3 * * *$ \\
\hline $5-8$ years & 32 & 50 & 78 & 16 & 10 & 23 & -9 & $-3-$ & $2 * * * * *$ \\
\hline 9-11 years & 37 & 48 & 54 & 3 & 8 & $20 *$ & -8 & -3 & $2 * * * * *$ \\
\hline 12 or more & 28 & 31 & 48 & -21 & -12 & $-4 * * *$ & -27 & -13 & -12 \\
\hline General & 41 & 50 & 65 & 2 & 7 & 16 & -10 & -4 & $1 * * *$ \\
\hline
\end{tabular}

*1993 non-significant at 5\%; ** 1996 non-significant at 5\%; ** 1999 non-significant at 5\%

Nevertheless, one notices that the gap is higher for the less qualified groups; therefore, one can assert that their members are paid better relative wages (using as a basis for comparison the wages paid to workers with the same characteristics in the private sector) than the members of the better-qualified groups.

The scenario described in the last section showed that the gross wage gap (without controls) between the public and private sectors has increased during the 1990s. Throughout this section, controls have been added to the calculation of the gap and a similar behaviour has been noticed. Since the inclusion of these controls brings about a considerable drop in the magnitude of the gap, the specificity of the makeup of the labour force explains a considerable part of the latter. The stratification of the analysis according to intervals of years of study has also indicated an evolution of the public/private gap during the decade, and, at the end of the period there was only one group in the public sector, amongst those analysed, whose gap was negative. The major differences were found for the groups with less schooling.

Thus, one can assert that even after the inclusion of different sorts of control - that is, taking into account different criteria that have allowed us to compare workers with similar characteristics - wages in the public sector are higher than those paid in the private sector. More than that, since controlled wages are different in the two sectors, the segmentation between the two markets is thus characterized and, consequently, there must be others factors that influence the wage setting in the public sector in addition to those discussed in this section. The next sections will suggest some of these factors and look for the empirical verification of the assumptions presented therein.

\section{THE WAGE SETTING IN THE PUBLIC SECTOR}

In the previous section, we have seen that even taking into account different controls for the personal characteristics, for the trade-union activity and the geographic location of workers - which are important determinants of relative wag- 
es - , compensations in the public sector proved to be different from those paid in the private sector. Therefore, the conclusion is that other factors, in addition to the ones already discussed, contribute for the explanation of the wage setting in the former.

The public sector has objectives that are different from those of the private sector, namely, and in a summarised form, to foster economic growth, to maintain order and to promote social justice. In order to reach these goals, it makes exchanges and transfers with the private sector. This process involves political decisions, since governments may choose to gear their expenditure in order to favour more directly or more intensely certain groups within society. Since the characteristics of the dynamics of the public sector will influence the functioning of its labour market, the political variables end up by being important in the definition of the behaviour of this market. While in the private sector decisions are made within an environment that privileges economic variables (without disregarding the political ones), in the public sector the political factors acquire a more relevant weight in the decisionmaking process.

Along this line of reasoning, decisions in the public sector may aim at objectives of equity and social justice, in order to maximise the welfare of society - or of social groups towards which specific policies are geared -, of efficiency - obtaining the best results from a given policy at lesser cost — or they may be aimed at achieving personal objectives or the objectives of certain groups on the part of politicians interested in creating better conditions for their permanence in office.

These characteristics will be of consequence for the functioning of the labour market of the public sector. According to Gregory and Borland (1999), if politicians or bureaucrats are concerned with attaining efficiency, they may choose a combination of employment and wages in the public sector apt to minimise production costs. If they are more concerned with achieving objectives related to equity, managers may concern themselves with the definition of a minimal level of employees belonging to certain demographic groups, in order to reduce the failures recorded in other labour markets (such as discrimination), or with using public employment as a mechanism aimed at reducing the level of unemployment of an economy. And, on the other hand, if they are concerned with the achievement of personal objectives — politicians by means of the possibility of obtaining a larger number of voters, and bureaucrats by means of the appropriation of a bigger share of the budget employment and wages will probably be established above the level of efficiency.

The basic model for the wage setting in the public sector should take into account, at first, a strong constraint brought about by the need for maintaining intertemporal budgetary equilibrium. The limitation that exists for personnel-related expenditure causes it to be necessary for rulers to choose a given combination between employment and wage as in a curb of budgetary constraint in which a combination is decided upon the amount consumed of two goods.

Consequently, the magnitude of the budget of a specific ministry, department or organisation (or, in the case of government as a whole, of its available revenue) 
will play a fundamental role in the definition of its threshold for the personnelrelated expenditure, or of the total of wages spent with its employees.

When the budget of a ministry increases, there would be a trend towards a raise of the wages of its members, as well as of employment in the organisation, which would bring about a displacement of the curb of personnel-related expenditure that might be characterised as an income effect. Nevertheless, the higher is the level of employment, the stronger is the impact of a raise in the wage on the payroll and, if the equilibrium budgetary constraint is maintained, the marginal cost (for the payroll) associated to the raise of the wage would be increasing.

Therefore, the wage raise will not be so intense if employment also evolves when there is an expansion of the budget of the ministry and, in this case, there will be something similar to a substitution effect between wage and employment (with the corresponding reduction of the former). The combination between wages and employment that would allow for the achievement of the level of production desired by the executives or the politicians in the agency would change (it would be equivalent to saying that, in the point of equilibrium the marginal gain in terms of votes, deriving from the production brought about by higher expenses related to employment, should equate its respective marginal costs). ${ }^{13}$

In other words, government will choose an optimal combination of employment and wages that will determine the extent of its political support and maximize its return in terms of votes, whether by means of the criterion of efficiency - increasing welfare starting from a given level of production of services - or by means of meeting the demands of voters who look for employment opportunities or good wages in the public sector.

Once highlighted the constraint deriving from the level of employment, the analysis will be specifically geared to the issue of wages.

Government is made up of different ministries, or public organizations, by means of which it performs the activities provided for in its programme. ${ }^{14}$ These activities are, in turn, carried out by bureaucrats, who control the flow of information and production of the ministry and thus provide political support for government. Therefore, to the extent that government tries to implement the different points of its programme and thus achieve its objectives and more support from society, which is translated into votes, it will have to pay good wages to the bureaucracy, which may hamper the flow of production when wage is low, or increase it when wage is higher.

Thus, the degree of organization of the bureaucracy is an important factor in the definition of the levels of wage paid to employees. United, well organized and not too disperse groups are in better position for organizing an internal labour market and hampering the flow of work in an institution. This market is further

\footnotetext{
${ }^{13}$ If a budgetary constraint is disrespected and brings about deficit, the effect corresponds to a displacement of this curb.

14 This model is, in part, based upon Borjas (1980).
} 
reinforced by a relative barrier to entrance into the sector, once defined the need for public open competitions for admittance. Furthermore, the greater the relevance of the activities of the agency, the greater will be the bargaining power of its employees.

The budget of the ministry will increase to the extent that the return in terms of votes or welfare of the production of the agency is growing. Ministries (or departments) whose activity is more relevant within a government programme should have a larger budget and thus the wages of its civil servants may also be higher, in order to prevent the performance of the organization from being jeopardized by a possible shirking or insufficient commitment of the bureaucracy regarding its tasks.

The higher level of relevance of the ministry may be a consequence of its importance within a government plan, of the qualification of the audience that benefits from its activities (and from its capability to increase the number of votes for the benefactors), that is, its degree of political organization and influence on the electoral outcomes and even the amount of individuals that benefits from the actions of such organization.

Therefore, the combination between a significant degree of organization of workers and the relevance of the activities of the agency will boost the bargaining power of the bureaucracy and will improve the conditions in which it is able to negotiate its wages, even because in this case the budget allocated to this ministry should be relatively larger.

This logic may also be analysed from the standpoint of efficiency, for government may pay good wages in order to avoid the drop in productivity and the deterioration of services rendered or even the emergence of corruption. Furthermore, bureaucrats tend to be employees who remain for a long period in the discharge of their activities and, as a rule, acquire a large stock of specific human capital, also based upon the knowledge of bureaucratic rules that are quite typical of the functioning of the different sectors. The internal labour market deriving from this dynamics ends up by generating the need for practising an efficiency wage for its members.

Furthermore, since they are also voters, the operation of the bureaucrats as an organized block ends up by significantly influencing the result of elections, particularly at local level. This fact inhibits employers in terms of their opposition to the claims of workers and to the very trade-union operation. Along this line of reasoning, the interests of politicians and trade unions may coincide and the operation of the latter would face fewer constraints in the public sector than those recorded in the private sector.

This logic is only possible if society accepts to pay this personnel bill or, in other words, accepts the charges of a greater tax burden (always under the assumption that the budgetary constraint will be respected). Society may accept it if the service delivered by given agency is strategic, if a significant part of the resources that will fund this expenditure represents a burden for the population of other cities, or if society counts on imperfect information on the behaviour of government expenditure. 
If the sector is strategic, society admits to absorb higher expenditure because the service offered is most relevant for the other economic activities or for the welfare of the population. Thus, it is accepted to pay an efficiency wage to employees.

If a significant part of the population benefits from higher wages (or from a higher level of employment), then civil servants would even accept to contribute for the funding of this expenditure, provided that the benefits received were higher than the costs involved therein. Indeed, from the point of view of workers of the public sector, it is advantageous to receive a wage raise because the cost is shared by the whole society. The magnitude of this benefit may be represented by the number of individuals in this region that benefit from the growing personnel-related expenditure, which may be measured in several ways, such as by the number of voters that benefit from this policy and by the relevance the compensation paid to civil servants assumes in the make-up of family income.

If we think of the model of general equilibrium, nonetheless, someone will have to absorb these higher costs, since for those who are not workers of the public sector, this strategy only brings about burdens.

The existence of a large number of beneficiaries only adds to the need for funding agents for this strategy. While civil servants benefit from it, society as a whole (therefore, both public and private workers) has to absorb the raise of taxes or the reduction of consumption (or investment) of government in others items. Therefore, civil servants would be both beneficiaries and funding agents of this strategy, while the workers of the private sector would be only funding agents. The constant overload of taxes on the later would impede, in the medium run, the maintenance of this dynamics. But there are two possibilities so that this process may last and the population of a given city may continue accepting such level of expenditure.

The first one establishes that this strategy becomes feasible if a portion of the taxes collected by the local government is deriving from non-residents (for instance, if a good part of the production of this city or state is sold in other ones) or if a significant part of the revenues derives from transfers from other cities (or states) or spheres of government, which is for instance characteristic of the states and more intensely so of Brazilian municipalities.

The other possibility is the occurrence of a principal-agent problem. Bureaucrats would have their own objectives - they would be the agents - though at the cost of bringing about a less satisfactory outcome for the principal, which would correspond to society or, in the specific case, to taxpayers, who would absorb the higher tax burden necessary for the payment of higher personnel-related expenditure. The control on a bureaucracy would be hindered by the reduced information on which society counts on the activities developed and the expenditure ensuing from the maintenance of the corps of employees, which facilitates bureaucrats influencing the allocation of resources for their own benefit.

Indeed, there is not a habit on the part of society in terms of appropriately controlling the expenditure with bureaucracy. Specifically in the Brazilian case, inflation used to strongly distort budgetary results, which were always accounted for in nominal terms in its balance sheets, a fact that did not allow for a precise 
and detailed analysis of expenditure and that helped mask negative results. Employees, in turn, always enjoyed better conditions for following the budgetary execution and exercising pressure in favour of a higher allocation of funds for personnel-related expenditure, given their access to information or the proximity of the decisionmaking process. This situation is recorded still in a more intense manner at localgovernment level, where public accounting is precarious to date.

This asymmetry of information brings about, therefore, the principal-agent problem described above. Thus, though the largest portion of society absorbs a cost higher than the benefits deriving from the wage raise (which apply only to a part of society and the impact of which on the improvement of services delivered is, in general, unknown by most of population), the lack of information may lead them to fund these higher costs, although they may seem irrational and bring about an equilibrium that is not efficient.

The institutional environment in which wages are established will also be important, since the processes of wage setting vary according to the different characteristics of the labour market of the public sector. At federal level, for instance, the process of wage setting must be more rigid and bureaucratic than at state and municipality level, where the rules may even be associated to the characteristics recorded in the local labour markets. Furthermore, at some levels the wage may be established with little intervention of workers and at others, through a greater process of negotiation. This distinction may occur, for instance, when at one level the wage is established by law (which not necessarily impedes bargaining, but gives more decision-making power to employers) and at other levels is the result of collective negotiation. ${ }^{15}$

From the standpoint of equity, government might implement pro-active, antidiscriminatory policies aimed at equal access to the opportunities available, in order to practise a wage gap smaller than the one recorded in the private sector regarding the ethnic group or gender, and it might as well try to operate in an anticyclical manner vis-à-vis the level of activity, avoiding both the reduction of wages and the reduction of employment during periods of recession (or making an option for one of them).

After this discussion, is possible to assert that the wages of civil servants would be defined by:

$$
\begin{aligned}
& W_{i}=W_{i c} *\left(1+R_{1 i}\right) *\left(1+R_{2 i}\right), \\
& W_{i c}=f \text { (gender, colour, age, schooling, work experience) } \\
& R_{1 i}=f \text { (geographic location and bargaining power of workers) } \\
& R_{2 i}=f \text { (available revenue, participation of the transfers in the budgetary rev- }
\end{aligned}
$$

\footnotetext{
${ }^{15}$ In the Brazilian case, for instance, this distinction is recorded between statute-governed civil servants and employees governed by the Consolidation of Labour Acts, although, anyway, the former also ends up by exercising pressure and negotiating their wages. The major difference is the fact that, if government chooses to absorb the political burden and to set the wage at a given threshold, below the one desired by statute-governed civil servants, it can do it by law, without incurring in the risk of having to negotiate the issue in Labour-Law Courts.
} 
enue, political relevance of the activities of the ministry or agency, pressure of the bureaucrats as voters, level of information of society on government expenditure, proximity to the decision-making process, institutional environment, quest for equity in the structure of compensation) Subject to the following constraint:

$$
T=\sum_{t_{t}}^{k} \mathbb{W}_{L} \quad t=1
$$

Where:

$W_{i}=$ wage of the individual $i$

$W_{i c}=$ portion of the wage of the individual $i$ that depends upon his or her demographic and productive characteristics

$R_{1 i}=$ reward or economic rent upon the wage determined by the personal characteristics

$R_{2 i}$ = set of factors that will specifically influence the wage setting in the public sector and the interaction of which will bring about the wage gap upon those paid for their peers in the private sector ${ }^{16}$

$T$ = budgetary revenue allocated for the personnel-related expenditure

$W_{t}=$ average wage practised in the ministry (or agency) $t$

$L_{t}=$ level of employment in the ministry (or agency) $t$

$k=$ number of organizations in the public sector

In the next section, different tests will be carried, trying to verify, using as an example the behaviour of the wages of state statute-governed civil servants, the explanatory power of some of these factors in the process of wage setting in public service.

\section{THE EMPIRICAL ANALYSIS: WAGES OF STATUTE-GOVERNED STATE CIVIL SERVANTS}

This section will discuss the factors that influence the wage setting for state civil servants, and the analysis will focus on statute-governed civil servants for the reasons previously discussed. We shall try to demonstrate that the wage setting for these civil servants is associated to the conditions of local markets, in addition to being determined by political factors that are more relevant at state level.

We shall be using data of the PNAD's of 1995, 1996 and 1997 for the study of the factors that determine the wages of state public civil servants, since part of the data included in this last test are available only for this period.

The wage setting for state civil servants must be associated to the conditions of the local labour markets, whether by political or economic factors. First of all, it is

\footnotetext{
${ }^{16}$ The degree of strengthening of the internal labour market, for instance, is an important factor for the wage setting in the public sector, but is not specific, to the extent that it is a variable that may also influence the wage setting in the private sector, thus contributing to the increase of the bargaining power of workers.
} 
necessary to take into account the fact that the legislation governing the wages of these civil servants is defined at local level, contrary to the one pertaining to federal civil servants, which is uniform for the whole country. This implies that the likelihood of taking into account the regional characteristics in the preparation of the laws that establish the wage levels is quite higher, since the preliminary discussions will certainly include the economic and political peculiar traits of the state at issue.

In order to assess whether the regional economic conditions contribute for the wage setting for state civil servants, the behaviour of the level of activity in each state should be taken into account in the model to be tested.

The situation of government budget - particularly of tax collection - will also influence this process. Since the behaviour of tax collection of Brazilian states is under a strong influence of the transfers from others spheres of government (which substantially alters its volume and make-up in some cases), this will be a factor of paramount importance, since those states that count on a higher participation of net transferred resources in their tax-collection structure tend to be more flexible in granting wage raises, as discussed in the previous section.

Alternatively, if society is not well informed on the destination of public funds, it is likely a principal-agent problem will occur, as described above and, in this case, it is possible that wages raise when there is an increase of the available revenue irrespective of the participation of transfers received in this revenue, even if such raise comes, priority-wise, from taxes collected from local residents.

From the political point of view, the electorate is closer to the members of houses of representatives and other political agents at local than at federal level, and therefore the legislator should be more sensitive in what regards the wage-related demands of civil servants, particularly if there is a considerable number of voters who at the same time are civil servants. Thus, in those places where there is a relative higher participation of civil servants in the make-up of the electorate, politicians tend to be more flexible in what concerns wage policy, particularly in the states that have a significant availability of resources or in those whose participation of revenues coming from other spheres is relevant, which facilitates the quest for political support by means of the raise of employment or wages for public service.

The tests below will try to measure the factors that influence the determination of the wages of statute-governed state civil servants, by using the variables adopted in the more general model in order to explain the behaviour of wages, as defined in the second section and, furthermore, taking into account other variables that reflect the economic conditions in force in the local markets and the political influences in the process of wage setting for the state civil servants. ${ }^{17}$

\footnotetext{
${ }^{17}$ Amongst the specific factors of the process of the wage setting for statute-governed state civil servants we shall include those that are susceptible of measuring and the information on which be available in the PNADs or in official reports on fiscal results. Thus, the variables regarding the political relevance of the activities of the ministry or of the agency (since the identification of the organization of origin of civil servants would stratify too much the sample and the group of employees representative of each
} 
The state per capita GDP seems to be a variable that appropriately reflects the economic conditions of a region. In addition to taking into account the growth of income, it reflects the growth of productivity - that is an important factor for the determination of wages - and, in the medium run, the fluctuations of employment.

Since in the states where the participation of revenues coming from other spheres of government is higher there should be more readiness for (or less resistance to) the practice of higher wages or the recruitment of a larger volume of civil servants, a variable should be included in the test to reflect the relationship between the net transfers (received transfers subtracted from granted transfers) and the tax revenue added of the social-security contributions for the different state governments (according to the concept used by IBGE in the counting of the results of public administrations $)^{18}$.

Under the assumption that taxpayers would agree to wage raises (for civil servants) constantly linked to the increase of revenue raise that represents a burden for them (taxpayers), when it will be perceived the relevance and efficiency of services delivered or there is a lack of information (which would bring about an principal-agent problem), an alternative test will be carried out where the variable that measures the participation of transfers in the revenue will be replaced by the indicator that reflects the behaviour of the available revenue. The latter corresponds to the tax revenue added of the social-security contributions and of the intergovernmental transfers received, subtracted from granted intergovernmental transfers, visà-vis GDP, also according to the concept adopted by IBGE.

Regarding the strictly political variables, it is important to take into account the impact that civil servants, in their capacity as electors, exercise on the decision of the rulers vis-à-vis the wage levels practised. Thus, in places where the participation of civil servants in the electorate is higher - or, of more widely, the participation of individuals whose income is influenced by the wage of civil servants - their political pressure for obtaining higher wages, irrespective of being implicit or manifest, is more intense, because politicians know that civil servants - and those that receive some benefit deriving from the wage of the latter - make up a significant part of their electoral basis. Thus, another relevant variable to be taken into account in the model is the percentage participation, in each state, of the number of voters in families of civil servants vis-à-vis the total number of voters. ${ }^{19}$

The models adopted in these regressions would be the following:

agency would be too reduced), proximity of the decision-making process and quest for equity in the structure of compensation will not be included in the model (although the latter may be partially captured by means of the behaviour of the coefficients pertaining to discrimination). In turn, one assumes that the level of information of society on the expenditure of government is associated to the frequency and/or intensity of occurrence of wage raises deriving from growth of the revenue available that burdens primarily local taxpayers.

${ }^{18}$ See IBGE (2000: 29), volume 1.

${ }^{19}$ The number of voters was estimated starting from the counting of all individuals over the age of 18 included in the sample of PNAD used in the calculations. 
(A) $\operatorname{Ln} W_{i}=a+\left(b^{*} \operatorname{age}_{i}\right)+\left(c^{*} \operatorname{age}_{i}^{2}\right)+\left(d^{*} \operatorname{gender}_{i}\right)+(e *$ years of study $i)+$ $\left(f *\right.$ colour $\left._{i}\right)+(g *$ years of experience $i)+\left(h *\right.$ trade union $\left._{i}\right)+(j *$ Per capita GDP $i)$ $+\left(k *\right.$ net transfers $/$ revenue $\left._{i}\right)+(l *$ percentage participation of civil servants in the electorate $\left.{ }_{i}\right)$

(B) Alternatively, including the available revenue/GDP ${ }_{\mathrm{i}}$ instead of net transfers/ revenue $_{i}$; the other variables remain the same.

Where:

Per capita GDP $=$ Per capita GDP of the state where individual $i$ is, with values at 1997 prices

Net transfers/revenue $=($ intergovernmental transfers received $(-)$ intergovernmental transfers granted) / (tax revenue $(+)$ social-security contributions), for the state where individual $i$ is

Available revenue/GDP $=($ tax revenue $(+)$ social-security contributions $(+)$ intergovernmental transfers received (-) intergovernmental transfers granted) / GDP, for the state where the individual $i$ is

Percentage participation of civil servants in the electorate $=$ Number of voters in families of civil servants / total of voters, for the state where the individual $i$ is

And the other definitions, already presented in the initial model, remain the same.

The values of per capita GDP were obtained starting from the Regional Accounts of Brazil, calculated by IBGE, and the budgetary data of the state governments were also surveyed in the reports published by IBGE and pertaining to the regional processing of the transactions of the public sector. The other data come from the PNAD. We did not include dummies for the states because these were replaced by the information pertaining to each of them (per capita GDP, budgetary data and electorate, which information was taken into account under the form of index numbers).

Data pertaining to 1995, 1996 and 1997 were taken into account in the analysis because the information pertaining to previous years might bring about significant distortions as a consequence of the process of deflation (the data are annual and correspond to a flow, in the case of GDP and of the budget) and the budgetary information for subsequent years were not made available by IBGE (at least with the same methodology). The data for the three years chosen were included in the same regression, which thus combines the temporal and cross-section (pooled cross section) analysis. The tests only took into account statute-governed civil servants, due to the arguments already presented.

The results obtained are presented in table 5. First of all, one notices that most of the variables of control pertaining to the personal characteristics, geographic location and trade-union membership present expected results (with the exception of the dummies pertaining to gender and colour of the individual) and all of them are significant, that is, they are important factors for the wage setting for state civil servants. The dummies of gender and colour show the existence of discrimination also in the public sector, a fact that raises the hypothesis of absence of proac- 
tive policies meant to reduce this distortion of the labour market, since the gap is high in both cases. ${ }^{20}$

In order to assess whether the state rulers and legislators have been at least trying to be fairer vis-à-vis this subject than the private sector, table 6 shows two regressions, one for the private sector and another for the public sector, which include only the personal characteristics and trade-union membership as explicative variables and wage as an endogenous variable. The results show that the gap per gender is still higher in the public sector than in the private sector, while the difference related to colour is lesser. Thus, the public sector would present a lesser degree of discrimination in what concerns the colour than as far as gender is concerned, as compared to the private sector. ${ }^{21}$

Regarding the other variables - that would be the ones corresponding to the specific factors of the wage setting for state civil servants - the results included in table 5 shows that all of them are significant. Nevertheless, the magnitude of the coefficients varies considerably, particularly in what concerns the participation of transfers in the revenue, demonstrating that such factors do not have similar relevance in the process of the wage setting in the public sector. ${ }^{22}$

The per capita GDP is a relevant variable in this process, proving that the economic conditions of a region, which influence the functioning of the local labour market, are important in the definition of these wages, which, thus, do not seem to assume in the public sector a counter-cyclic character vis-à-vis the level of activity.

Greater participation of individuals in the electorate whose income is influenced by that of civil servants also ensures the practice of higher wages, showing that the concern of politicians with the behaviour of their voters is an important political component of the process of wage setting in the public sector.

On the other hand, the coefficient of the variable that measures the influence, in this process, of the participation of revenues coming from others states and spheres of government in the total revenue (included in the regression A in table 5), although statistically significant, does not present relevant magnitude, indicating that the wages vary very little in response to the changes in such participation. In turn, the variations in the available revenue (variable included in the regression B in the table 5) would seem to more intensely influence the wage setting in the public sector.

\footnotetext{
${ }^{20} \mathrm{The}^{2}$ of the equation pertaining to the regression A in table 5 reached 0.421 and of the one pertaining to regression $\mathrm{B}$ in table 5 reached 0.42 .

${ }^{21}$ The $r^{2}$ of the equation pertaining to the workers of the private sector reached 0.418 and the one pertaining to state statute-governed civil servants reached 0.366 . One also notices that the private sector seems to better value the specific human capital than the public sector, in view of the difference between the values of the coefficients for age and years of experience.

${ }^{22}$ Since these variables are under the form of index numbers, the coefficients of GDP and of the number of voters in families of civil servants, for example, indicate that a change of 5 points in the respective index numbers brings about a change of approximately $1 \%$ in the wages, in each case. It does not seem to be an expendable variation. In the case of the revenue available the variation recorded would correspond to approximately $0.5 \%$, in the same situation, and for the transfers it would be quite smaller.
} 
Thus, it seems that there really is a principal-agent problem in the process of wage setting for civil servants, possibly due to asymmetric information, since the link between raises of revenue and of wages is more important than the one recorded between the ratio transfers/revenues and the evolution of wages. In view of this behaviour, it is possible that there is no resistance on the part of society to raises of wages deriving from the growth of revenue arising from the tax collection which falls upon local taxpayers and, thus, implies further burden for them. This scenario is only possible under the assumption that the agents operate in a rational manner due to a problem of lack of information. ${ }^{23}$

Complementing the analysis, the data of tables 1 and 2 show that, during the 1990s, state governments choose raises in the levels of wage instead of increases in the level of employment. While the later was reduced (particularly in the group of employees governed by the Consolidation of Labour Acts, while in that of statutegoverned civil servants it has remained relatively constant), the average wage rose for both groups (mostly for statute-governed civil servants). There has been

Table 5: Wages of State Statute-Governed Civil Servants (coefficients in \%, except for the constant) - 1995 to 1997

\begin{tabular}{|c|c|c|}
\hline & $\begin{array}{l}\text { Regression A } \\
\text { (taking into account } \\
\text { the ratio between } \\
\text { transfers and revenue) }\end{array}$ & $\begin{array}{c}\text { Regression B } \\
\text { (taking into account } \\
\text { the available } \\
\text { revenue) }\end{array}$ \\
\hline Constant & 33 & 33 \\
\hline Gender & 40 & 39 \\
\hline Colour & 10 & 10 \\
\hline Trade-union membership & 15 & 16 \\
\hline Age & 2,8 & 2,8 \\
\hline Age $\wedge 2$ & $-0,02$ & $-0,02$ \\
\hline Years of Study & 12 & 12 \\
\hline Years of Experience & 1 & 1 \\
\hline Per capita GDP & 0,227 & 0,226 \\
\hline $\begin{array}{l}\% \text { voters in families of civil servants / } \\
\text { total voters }\end{array}$ & 0,2 & 0,21 \\
\hline $\begin{array}{l}\text { Net transfers / } \\
\text { (Tax Revenue + Social-Security Contributions) }\end{array}$ & 0,048 & \\
\hline Available revenue / GDP & & 0,102 \\
\hline
\end{tabular}

The anti-log of the constant is not multiplied by 100

23 The hypothesis that society would accept to absorb an efficiency wage due to the strategic relevance of the service offered applies according to sectors, but not for the whole government, because in this last case there necessarily occurs a raise of personnel-related expenditure - the burden of which strongly falls upon taxpayers -, which fact, according to the analyses presented in this paper, has been taking place in the state public sector. 
an adjustment on the level of employment, focused on employees governed by the Consolidation of Labour Acts and that did not reach wages; consequently, it is possible to take into account that, in the process of choice of the allocation of resources meant for employment or wages, in view of the budgetary constraint, the politicians of the state sphere have privileged the latter during the previous decade.

\section{Table 6: WAGES OF STATE STATUTE-GOVERNED CIVIL SERVANTS AND OF PRIVATE SECTOR WORKERS}

(coefficients in \%, except for the constant) - 1995 to 1997

(taking into account only the personal characteristics and trade-union membership)

\begin{tabular}{lcc}
\hline & $\begin{array}{c}\text { Statute-governed } \\
\text { civil servants }\end{array}$ & $\begin{array}{c}\text { Private Sector } \\
\text { workers }\end{array}$ \\
\hline Constant & 63 & 22 \\
\hline Gender & 41 & 37 \\
\hline Colour & 17 & 29 \\
\hline Trade-union membership & 21 & 24 \\
\hline Age & 2,4 & 7,3 \\
\hline Age $\wedge$ 2 & $-0,02$ & $-0,07$ \\
\hline Years of Study & 12 & 11 \\
\hline Years of Experience & 0,8 & 2,0 \\
\hline
\end{tabular}

The anti-log of the constant is not multiplied by 100

\section{CONCLUSION}

To conclude, the wages of state civil servants seem to suffer the influence of the conditions of local labour markets. It is significant for a definition of such wages to take into account the behaviour of the demographic and productive variables, as well as the degree of unionization of the labour force; but there are other factors that influence the process of establishment of these wages, related to the availability of budgetary resources for government, and there seems to occur an principalagent problem that allows for the destination of marginal increases in tax collection (or a part of them) for wage raises in the public sector. Furthermore, the participation of civil servants and of members of their families in the make-up of the electorate, which determines the relevance of this group for the definition of the electoral outcomes, will also contribute to this process. Regarding the policies aimed for correction of the distortions that occur in the labour market, the public sector seems to demonstrate a lower degree of colour discrimination. Thus, politi$\mathrm{cal}$ and economic factors related to the local characteristics would be fundamental for the determination of the wages of state civil servants. 


\section{REFERENCES}

ALTONJI, Joseph G. and Rebecca M. BLANK (1999) "Race and Gender in the Labor Market", in Ashenfelter, O. and R. Layard, eds. (1999), vol. 3.

ASHENFELTER, O. and R. LAYARD, eds. (1986) Handbook of Labor Economics, Elsevier Science Publishers BV, vols. 1 and 2.

ASHENFELTER, O. and R. LAYARD, eds. (1999) Handbook of Labor Economics, Elsevier Science Publishers BV, vol. 3.

BARROS, Ricardo P., Miguel N. FOGUEL and Rosane MENDONÇA (1997) “The Wage Gap between the Public and Private Sectors in Brazil”, Série Seminários n. 13/97. Rio de Janeiro: IPEA.

BORJAS, George J. (1980) "Wage Determination in the Federal Government: the Role of Constituents and Bureaucrats", Journal of Political Economy, 88(6).

BRESSER-PEREIRA, Luiz Carlos (1996) Crise Econômica e Reforma do Estado no Brasil. São Paulo: Editora 34.

CAIN, Glen G. (1986) “The Economic Analysis of Labor Market Discrimination: a Survey”, in ASHENFELTER, O. and R. LAYARD, eds. (1986), vol. 2.

DOERINGER, Peter B. and Michael J. PIORE (1971) Internal Labor Markets and Manpower Analysis. Lexington, MA: D.C. Heath and Company.

EHRENBERG, Ronald G. and Joshua L. SCHWARZ (1986) "Public Sector Labor Markets", in ASHENFELTER, O. and R. LAYARD, eds. (1986), vol. 2.

FERNANDES, Reynaldo (2000) Desigualdade Salarial: Aspectos Teóricos. São Paulo: Universidade de São Paulo, mimeo.

FOGEL, Walter and David LEWIN (1974) “Wage Determination in the Public Sector”, Industrial and Labor Relations Review, April 1974.

GILL, Indermit, Miguel FOGUEL, Rosane MENDONÇA and Ricardo PAES DE BARROS (1997) Brazil: Sustaining the Real Plan Through Sustainable Public Employment Reforms, mimeo.

GREGORY, Robert G. and Jeff BORLAND (1999) "Recent Developments in Public Sector Labor Markets", in ASHENFELTER, O. and R. LAYARD, eds. (1999), vol. 3.

IBGE (1999) Contas Regionais do Brasil 1985-1997. Rio de Janeiro: IBGE.

IBGE (2000) Regionalização das Transações do Setor Público: Atividade de Administração Pública 1991-1997. Rio de Janeiro: IBGE.

KATZ, Lawrence F. and David H. AUTHOR (1999) "Changes in the Wage Structure and Earnings Inequality”, in ASHENFELTER, O. and R. LAYARD, eds. (1999), vol. 3.

LINDBECK, Assar and Dennis J. SNOWER (1987) "Efficiency Wages versus Insiders and Outsiders", European Economic Review, vol. 31.

MACEDO, Roberto (1985) Os Salários nas Empresas Estatais. São Paulo: Editora Nobel.

REDER, Melvin (1973) “The Theory of Employment and Wages in Non-Profit Industry”, Working Paper

n. 42 A, Industrial Relations Section, Princeton University.

URANI, André and Mariana RAMALHO (1995) "A Administração Pública como Empregadora: uma Avaliação da Década de 80", Série Seminários n. 5/95. Rio de Janeiro: IPEA.

WILLIS, Robert J. (1986) "Wage Determinants: A Survey and Reinterpretation of Human Capital Earnings Functions”, in ASHENFELTER, O. and R. LAYARD, eds. (1986), vol. 1. 